\title{
The New Anthropometric Measures in Patients With Hypothyroidism
}

\section{Hipotiroidi Hastalarında Yeni Antropometrik Ölçümler}

\author{
Gülsüm GÖNÜLALAN 1 (D), Yusuf TANRIKULU ${ }^{2}$ \\ ${ }^{1}$ Department of Endocrinology and Metabolism, KTO Karatay University, School of Medicine, Medicana Konya Hospital, \\ Konya, TURKEY \\ 2 Department of General Surgery, KTO Karatay University, School of Medicine, Medicana Konya Hospital, Konya, TURKEY
}

Abstract

Background: We aimed to compare the new anthropometric measurements and traditional anthropometric measurements as body mass index which are used to display visceral adipose distribution in patients with hypothyroidism. We also aimed to investigate the new anthropometric measurements and Carotid intima media thickness as predictors of cardiovascular risk.

Materials and Methods: We include patients with hypothyroidism and healthy controls. The patients were divided into 3 groups as overt hypothyroidism, subclinical hypothyroidism and control groups. Demographic data, anthropometric measurements, laboratory findings and CIMT of the patients and control group were also evaluated.

Results: The mean ages of the patients in groups were $37.46 \pm 8.89,35.03 \pm 13.06$ and $38.79 \pm 10.46$ years respectively $(p=0.876)$. The average of waist circumference in overt hypothyroidism group was statistically higher than control $(p<0.01)$. The averages of waist circumference/height circumference in the hypothyroidism groups were statistically higher than the control. There was a strong correlation according to body adiposity index, abdominal volume index, and body roundness index as new anthropometric measurements and body mass index, waist circumference, hip circumference and waist/height ratio ( $r>0.750 p<0.001$ for all values). The mean value of carotid intima media thickness of the overt hypothyroidism group was significantly higher $(p<0.01)$.

Conclusions: We found strong correlations between new anthropometric and traditional anthropometric measurements in patient with hypothyroidism. Cardiometabolic risk has increased in patients with hypothyroidism, and routine use of new anthropometric measurements displaying body fat distribution and central obesity will be useful for early detection and treatment of cardiovascular complications.

Key Words: Hypothyroidism; Atherosclerosis; Anthropometry; Carotid intima-media thickness

Öz.

Amaç: Bu çalışmada visseral yağ dağılımını gösteren bel çevresi, beden kütle indeksi, bel kalça oranı ve bel boy oranı gibi geleneksel antropometrik ölçümler ile yeni andropometrik ölçümleri hipotiroidi hastalarımızda ölçmeyi amaçladık. Çalışmamızda ayrıca hipotiroidi hastalarında kardiyovasküler risk göstergesi olan karotis intima media kalınlıkları ile yeni antropometrik ölçümler arasındaki ilişkiyi göstermeyi amaçladık.

Materyal ve Metod: Çalışmaya Endokrinoloji ve Genel cerrahi polikliniğine başvuran hipotiroidi hastaları ile sağlıklı bireylerden oluşan kontrol grubu dahil edildi. Çalışmaya dahil edilen hastalar aşikar hipotiroidi, subklinik hipotiroidi ve kontrol grubu olarak 3 gruba ayrıldı. Tüm grupların demografik verileri, fizik muayene bulguları, antropometrik ölçümleri, serum total kolesterol, trigliserid, yüksek ve düşük yoğunluklu lipoproteinler, tiroid hormon düzeyleri ve HOMA-Insulin direnci düzeyleri kaydedildi. Tüm gruplara ilk muayenede karotis intima media kalınlıkları ölçüldü.

Bulgular: Aşikâr hipotriodi, subklinik hipotiroidi ve kontrol gorubunun yaş ortalamaları sırasıyla 37,46 \pm $8,89,35,03 \pm 13,06$ ve $38,79 \pm 10,46$ olarak saptandı $(p=0,876)$. Bel çevresi ortalaması aşikar hiporitoidi grubunda ötiroid gruba göre anlamlı olarak yüksekti $(p=0.005)$. Bel çevresi/boy çevresi ortalamaları hipotiroidi gruplarında ötiroidi grubuna göre anlamlı yüksekti $(p<0,05)$. Yeni ölçümlerden Vücut yağlanma indeksi, Vücut yuvarlaklık indeksi ve abdominal hacim indeksi ile klasik antrometrik ölçümler olan vücut kitle indeksi, bel ve kalça çevreleri ve bel/boy oranı arasında çok güçlü korelasyon saptandı (tüm değerler için $r>0.750$ ve $p<0.01$ ).

Sonuç: Hipotiroidizm hastalarında yeni antropometrik ölçümler ile geleneksel antropometrik ölçümler oldukça güçlü korelasyon göstermektedir. Hipotirodizm hastalarında kardiyometabolik risk artmıştır ve bu risklerin erken tespiti için özellikle vücut yağ dağılımını ve santral obeziteyi gösteren yeni antropometrik ölçümlerin rutin kullanımı faydalı olabilir.

Anahtar kelimeler: Hipotiroidizm; Ateroskleroz; Antropometri; Karotis İntima Media Kalınlığı.
Corresponding Author / Sorumlu Yazar

Dr. Gülsüm GÖNÜLALAN

Kılınçarslan Mah. Nurdağ Sk, 11/25

Selçuklu/ Konya, TURKEY

E-mail: gselcuklu@gmail.com

Received / Geliş Tarihi: 30.12.2020

Accepted / Kabul Tarihi: 08.03.2021

DOI: $10.35440 /$ hutfd. 850782 


\section{Introduction}

Thyroid hormone disorder is widely seen in society. There is subclinical hypothyroidism ( $\mathrm{SCH}$ ) having higher TSH and normal free T4 ratios differently from overt hypothyroidism in which higher TSH and lower free T4 ratios are observed (1). Since thyroid hormones play a critical role for the continuity of the metabolism, many systems in body are affected and findings, which might change according to the severity of the disease, occur in the event that they are insufficient. Obesity occurring with a decrease in energy expenditure is a metabolism disorder that might be observed with an increase in blood pressure, dyslipidaemia, insulin resistance, constipation, hypothyroidism (2). Determining amount and distribution of fat in body is significant for predicting problems that might be associated and determining risk factors. Cardiovascular disease risk and mortality are related with an increase in waist circumference (3). It has been shown that some conventional anthropometric measures might predict body fat distribution. Apart from body mass index (BMI) and waist circumference, there are values such as waist/hip ratio, waist/height ratio among these measures. Measurements of waist circumference and amount of intraabdominal fattening show a great correlation (4-5). Because of the limitations of these methods to estimate body fat ratio, new anthropometric measures as a body sharpness index $(A B S I)$, body roundness index (BRI), body adiposity index (BAI), abdominal volume index (AVI) have been developed recently depending on measurement of waist circumference (6-7).

In our study, we purposed to measure new anthropometric measures as a body sharpness index (ABSI), body roundness index (BRI), body adiposity index (BAI), abdominal volume index (AVI), which are commonly used to display visceral adipose distribution in patients with hypothyroidism. Investigation of the relationship between new anthropometric measures with other conventional anthropometric measurements and hypothyroidism shows the value of new anthropometric measurements, which are measured easily, might be substituted for conventional anthropometric measures in hypothyroidism.

\section{Materials and Methods \\ Study Plan and Patient Groups}

Patients with hypothyroidism who visited Endocrinology and Metabolism Disorders and General Surgery policlinics and healthy controls were included the study. The patients included in the study were divided into 3 groups: Overt Hypothyroidism Group ( $n=56)$ : Patients with low serum free T4 and/or free T3 level and high TSH level (>10 miu/l).

Subclinical Hypothyroidism Group ( $n=30)$ : Patients with normal serum free T4 and free T4 levels, high TSH level(>4miu/I).

Control Group ( $n=52)$ : Patients including healthy individuals who visited check-up polyclinic.
Patients with comorbidities as acute coronary syndrome, hearth failure, stroke, pulmonary embolism, diabetes mellitus, renal failure, immunological disease history, receiving levothyroxine treatment due to hypothyroidism and patients under 18 years old were excluded.

Demographic data, physical examination findings, anthropometric measurements, serum total cholesterol, triglyceride, HDL, LDL, thyroid hormone (TSH, sT3 and sT4) levels, insulin levels of all patients and the control group were recorded. This study has been approved by the Ethical Committee for Clinical Researches of KTO Karatay University (Date: 19/06/2020 Number:2020/045).

\section{Anthropometric Measurements}

All measurements were performed by the same physician. Anthropometric Measurements included the weight, height, and waist and hips circumference. Body Mass Index (BMI) was calculated by dividing body weight (kg) by the square of height $\left(\mathrm{m}^{2}\right)$. Waist circumference was measured at the midpoint between iliac crests and the lowest rib while standing. Hip circumference was measured at the widest part of the hips. The average of these two values was taken as the waist-hip-ratio.

Body adiposity index (BAI), abdominal volume index (AVI), body roundness index (BRI), a body shape index (ABSI) were calculated using formulas [6-7 ].

BAI (Males and Females) $=[$ Hip circumference $(\mathrm{cm}) /$ height $(m)$ 1.5]-18

$\mathrm{BRI}=364.2-365.5 \times \mathrm{x} 1$ - [(Waist circumference / $(2 \pi) 2) /$ (0.5xheight) 2]

$\mathrm{AVI}=[2 \mathrm{~cm}$ (Waist circumference) $2+0.7 \mathrm{~cm}$ (Waist-Hip) 2]/1,000

ABSI=Waist circumference $(B M I 2 / 3 x$ Height $1 / 2)$

Insulin resistance was calculated using homeostasis model assessment (HOMA) formula [Fasting insulin $(\mu \mathrm{U} / \mathrm{mL}) \times$ Fasting glucose (mg/dl)/405)]

\section{Carotid Artery Ultrasonography}

During the first examination, Carotid intima-media thickness (CIMT) measurements of the patients were made at the distance defined as the vein lumen echogenicity and media-adventitia echogenicity using LOGiQ P5 B-Mode UItrasonographic device TM. Three measurements were performed from $1 \mathrm{~cm}$ proximal to both main carotid artery bifurcations and CIMT measurements were performed only from the posterior wall. The average CIMT was calculated from the average of measurements which were performed three times on both arteries.

\section{Statistical Analysis}

SPSS (Statistical Package for Social Science) for Windows 15.0 package program was used to analysis of the data. Descriptive statistics for continuous variables were presented as mean \pm standard deviation. Whether there were differences among groups for continuous variables was evaluated by using One-Way ANOVA or Kruskal Wallis variance analysis. Mann-Whitney $U$ multiple variance analysis was used to evaluate which group was different when $p$ 
value was statistically significance. Chi-square test was used for the comparison of discrete variables. After the division of the patients into groups, Spearman's partial correlation coefficients were used to reveal the relationship between anthropometric measurements and biochemical measurements and CIMT in the patients of the subclinical hypothyroidism group. For all results, $\mathrm{p}<0.05$ value was accepted as statistically significant.

\section{Results}

The data belonging to the demographic, conventional and new anthropometric measures and laboratory parameters of the groups were summarized in Table 1. According to the obtained data, the means of age of the patients in the overt hypothyroidism, subclinical hypothyroidism and control groups were $37.46 \pm 8.89,35.03 \pm 13.06$ and 38.79 \pm 10.46 , respectively $(p=0.876)$. In all groups, female gender ratio was more than male gender ratio, and the distribution of groups were similar $(p=0.789)$.

When classical anthropometric measures were taken into consideration, there was not any statistically significance between groups in terms of averages of BMI and hip circumference ( $p>0.05$ both). The average of waist circumference in the overt hypothyroidism group was higher than the control group $(p<0.01)$. The averages of waist circumference/height circumference ratio in the groups of overt and subclinical hypothyroidism were higher than the control group ( $p=0.009$ and $p=0.023$ respectively). The ratio of waist circumference/hip circumference in the subclinical hypothyroidism group was significantly higher than the control group $(p<0.05)$.

$B R I$, which is one of the new indices, was significantly higher in both overt and subclinical hypothyroidism groups than the control group $(p<0.01$ and $p<0.05$ respectively). The averages of AVI and ABSI of the overt hypothyroidism group were statistically higher than the control group ( $p<0.01)$. We did not find any difference between groups in terms of BAI ( $p=0.348)$. The mean value of CIMT, which is used to assess cardiovascular disease risk, of the overt hypothyroidism group were significantly higher than the control group $(p<0.01)$.

There was not any difference in groups according to glucose, HDL and insulin averages, which are laboratory parameters ( $p>0.05$ in all). Additionally, we did not observed difference between groups in terms of HOMA-IR $(p=0.531)$. The values of total cholesterol, triglyceride and LDL of the overt hypothyroidism group were significantly higher than the control group ( $p<0.05$ for all).

The correlation analysis of measurements in subclinical hypothyroidism group is given in Table 2 . We found positive correlations between CIMT and waist and hip circumferences, which are used to detect cardiovascular risk ( $r$ $(p)=0.431(0.017)$ and $r(p)=0.413(0.023)$. There was a very strong correlation between $\mathrm{BAI}, \mathrm{BRI}$ and $\mathrm{AVI}$, which are among new indices used to determine the risk, and classical anthropometric measurements including BMI, waist and hip circumferences and waist/height ratio (for all values $r(p)=>0.750(<0.001)$. We did not find any significant correlation between HOMA-IR and other laboratory parameters and anthropometric measures.

\section{Discussion}

One of the most significant symptoms of hypothyroidism is weight gain. It is thought that central obesity and dyslipidaemia contribute to increased atherosclerosis risk in patients with hypothyroidism (8). There are studies which claim that although it is clinically asymptomatic, SCD might be associated with cardiovascular diseases (910).

Thyroid hormones play a crucial role in synthesis, metabolism and mobilization of lipids. The effect of thyroid hormones has a key role in lipoprotein metabolism which determines cholesterol synthesis (11). The effect of hypothyroidism on glucose metabolism and insulin resistance is disputable. In our study, there was no difference between groups according to the averages of glucose, $\mathrm{HDL}$ and insulin. Total cholesterol, triglyceride and LDL values of the overt hypothyroidism were significantly higher than control group. We did not detect any difference between the HOMA-IR averages of groups.

However, BMI is widely used in the diagnosis of obesity, it is just a rough ratio and it does not reflect abdominal adipose mass exactly. Waist circumference is more sensitive in this respect. Determining abdominal fat amount better provides an advantage in terms of detection of cardiovascular risk (4). While evaluating obesity, different anthropometric measures other than BMI were used in different studies and the relationship between their capacities to evaluate was tried to be revealed. It has been proved that waist circumference and waist-height ratios are the best anthropometric parameters to predict body fat ratio. The waist-height ratio $\geq 0.5$ is accepted to be an indicator of abdominal fattening (4-5). Eren et al, reported correlations between anthropometrics measurement as BMI, WC, WHR and central and total fat and insulin resistance indexes in obese prediabetic women (12). Similarly, we could not find any correlations between HOMA-IR and BMI, WC, HC, WHtR, WHR in patients with subclinical hypothyroidism. In another study, it was reported that waist-circumference and waist-height ratio would determine cardiovascular complications better than BMI and waist-hip ratio (13-14). Similarly to these studies, we did not find any difference between groups in terms of averages of BMI and hip circumference in our study. The average of waist circumference was significantly higher in the overt hypothyroidism group in comparison with the control group. The averages of waist/height ratio in the hypothyroidism groups were significantly higher than the control group. The waist/hip ratio of the subclinical hypothyroidism group was also significantly higher than the control group in our study. 
Table 1. The Evaluation of Parameters in Groups

\begin{tabular}{|c|c|c|c|c|}
\hline & $\begin{array}{l}\text { Overt hypothyroidism } \\
(\mathrm{n}=56)\end{array}$ & $\begin{array}{l}\text { Subclinic hypothyroidism } \\
(n=30)\end{array}$ & $\begin{array}{l}\text { Euthyroidism } \\
(\mathrm{n}=52)\end{array}$ & $p$ \\
\hline Age (year) & $37.46 \pm 8.89$ & $35.03 \pm 13.06$ & $38.79 \pm 10.46$ & 0.876 \\
\hline $\operatorname{Sex}(M / F)$ & $9 / 47$ & $4 / 26$ & $6 / 46$ & 0.789 \\
\hline \multicolumn{5}{|l|}{ Traditional Anthropometric index } \\
\hline $\mathrm{BMI}\left(\mathrm{kg} / \mathrm{m}^{2}\right)$ & $29.18 \pm 4.99$ & $29.87 \pm 5.09$ & $29.12 \pm 5.83$ & 0.858 \\
\hline WC (cm) & $94.48 \pm 12.43^{\mathrm{a}}$ & $92.20 \pm 9.52$ & $88.54 \pm 10.87$ & \\
\hline $\mathrm{HC}(\mathrm{cm})$ & $106.43 \pm 11.82$ & $103.70 \pm 10.99$ & $102.17 \pm 12.43$ & 0.231 \\
\hline WHtR & $0.58 \pm 0.07^{b}$ & $0.58 \pm 0.07^{*}$ & $0.55 \pm 0.07$ & \\
\hline WHR & $0.89 \pm 0.06$ & $0.89 \pm 0.04^{\#}$ & $0.87 \pm 0.05$ & 0.073 \\
\hline \multicolumn{5}{|l|}{ New Anthropometric index } \\
\hline BAI & $33.51 \pm 6.72$ & $34.10 \pm 6.74$ & $31.84 \pm 6.87$ & 0.348 \\
\hline BRI & $5.11 \pm 1.57^{b}$ & $5.11 \pm 1.48^{¥}$ & $4.40 \pm 1.50$ & \\
\hline AVI & $18.29 \pm 4.63^{c}$ & $17.28 \pm 3.58$ & $16.06 \pm 3.96$ & \\
\hline ABSI & $0.08 \pm 0.01^{\mathrm{d}}$ & $0.08 \pm 0.01$ & $0.07 \pm 0.01$ & \\
\hline CIMT & $0.58 \pm 0.11^{\mathrm{d}}$ & $0.61 \pm 0.11$ & $0.35 \pm 0.12$ & \\
\hline HOMA-IR & $2.47 \pm 1.40$ & $2.29 \pm 1.08$ & $2.86 \pm 3.97$ & 0.531 \\
\hline \multicolumn{5}{|l|}{ Thyroid Hormones } \\
\hline TSH & $28.92 \pm 38.04^{d}$ & $6.64 \pm 2.15^{d}$ & $1.87 \pm 1.01$ & \\
\hline fT3 & $2.66 \pm 0.66^{\mathrm{d}}$ & $2.92 \pm 0.29^{d}$ & $3.20 \pm 0.37$ & \\
\hline fT4 & $0.99 \pm 0.36^{\mathrm{e}}$ & $1.12 \pm 0.17$ & $1.31 \pm 1.35$ & \\
\hline \multicolumn{5}{|l|}{ Laboratory } \\
\hline Glucose & $88.95 \pm 9.06$ & $89.67 \pm 6.91$ & $90.00 \pm 7.71$ & 0.853 \\
\hline Total cholesterol (mg/dL) & $203.97 \pm 42.86^{f}$ & $197.23 \pm 37.01$ & $183.85 \pm 31.17$ & \\
\hline Triglyceride (mmol/L) & $1.46 \pm 0.53^{\mathrm{g}}$ & $1.36 \pm 0.64$ & $1.20 \pm 0,58$ & \\
\hline $\mathrm{HDL}(\mathrm{mmol} / \mathrm{L})$ & $1.23 \pm 0,30$ & $1.29 \pm 0.42$ & $1.25 \pm 0.33$ & 0.847 \\
\hline $\mathrm{LDL}(\mathrm{mg} / \mathrm{dL})$ & $128.91 \pm 40.19^{h}$ & $119.33 \pm 31.86$ & $108.90 \pm 27.19$ & \\
\hline Insülin (mlU/ml) & $11.14 \pm 5.79$ & $10.27 \pm 4.59$ & $12.54 \pm 16.74$ & 0.458 \\
\hline
\end{tabular}

$p^{a}=0.005, p^{b}=0.009, p^{c}=0.007, p^{d}<0.001, p^{e}=0.003, p^{f}=0.010, p^{g}=0.012$ and $p^{h}=0.007, p^{*}=0.023, p^{\sharp}=0.047, p^{*}=0.023$ in comparison with control group

Abb. ABSI; a body shape index , AVI; abdominal volume index, BAl; Body adiposity index BMI; Body Mass Index, BRl; body roundness index, CIMT;Carotid intima-media thickness, fT3; Free triiodothyronine, fT4; Free thyroxin, HC; Hip circumference (cm), HDL-C: High density lipoprotein cholesterol, HOMA-IR; homeostasis model assessment -Insulin resistance, LDL-C; Low density lipoprotein cholesterol,TSH; Thyroid stimulating hormone, WC;Waist circumference (cm), WHR; Waist-hip-ratio, WHtR; Waist-height ratio,

Table 2. Pearson correlation analysis of measurements in subclinical hypothyroidism group

\begin{tabular}{|c|c|c|c|c|c|}
\hline & BMI & WC & $\mathrm{HC}$ & WHtR & WHR \\
\hline \multicolumn{6}{|c|}{$\begin{array}{l}\text { Traditional Anthropometric in- } \\
\text { dex }\end{array}$} \\
\hline BMI & 1 & $0.825(<0.001)$ & $0.814(<0.001)$ & $0.860(<0.001)$ & $-0.063(0.739)$ \\
\hline WC & $0.825(<0.001)$ & 1 & $0.904(<0.001)$ & $0.924(<0.001)$ & $0.120(0.529)$ \\
\hline $\mathrm{HC}$ & $0.814(<0.001)$ & $0.904(<0.001)$ & 1 & $0.869(<0.001)$ & $-0.314(0.091)$ \\
\hline Waist-height ratio & $0.860(<0.001)$ & $0.924(<0.001)$ & $0.869(<0.001)$ & 1 & $0.033(0.864)$ \\
\hline Waist-hip ratio & $-0.063(0.739)$ & $0.120(0.529)$ & $-0.314(0.091)$ & $0.033(0.864)$ & 1 \\
\hline \multicolumn{6}{|c|}{$\begin{array}{l}\text { Traditional Anthropometric in- } \\
\text { dex }\end{array}$} \\
\hline $\mathrm{BAI}$ & $0.804(<0.001)$ & $0.753(<0.001)$ & $0.873(<0.001)$ & $0.912(<0.001)$ & $-0.352(0.056)$ \\
\hline BRI & $0.865(<0.001)$ & $0.917(<0.001)$ & $0.858(<0.001)$ & $0.998(<0.001)$ & $0.044(0.816)$ \\
\hline AVI & $0.837(<0.001)$ & $0.998(<0.001)$ & $0.907(<0.001)$ & $0.921(<0.001)$ & $0.108(0.570)$ \\
\hline ABSI & $-0.354(0.055)$ & $0.200(0.289)$ & $0.066(0.728)$ & $0.134(0.479)$ & $0.299(0.108)$ \\
\hline CIMT & $0.215(0.253)$ & $0.431(0.017)$ & $0.413(0.023)$ & $0.397(0.030)$ & $-0.050(0.816)$ \\
\hline HOMA-IR & $0.056(0.770)$ & $-0.018(0.926)$ & $0.000(0.998)$ & $0.010(0.959)$ & $-0.050(0.793)$ \\
\hline \multicolumn{6}{|l|}{ Laboratory } \\
\hline TSH & $-0.291(0.118)$ & $-0.237(0.207)$ & $-0.266(0.155)$ & $-0.291(0.119)$ & $0.096(0.614)$ \\
\hline Glucose & $0.139(0.462)$ & $0.218(0.246)$ & $0.196(0.299)$ & $0.069(0.719)$ & $0.069(0.719)$ \\
\hline Total cholesterol & $0.160(0.398)$ & $0.188(0.319)$ & $0.173(0.360)$ & $0.242(0.198)$ & $0.017(0.928)$ \\
\hline Triglyceride & $0.095(0.619)$ & $0.140(0.460)$ & $0.009(0.963)$ & $0.155(0.412)$ & $0.278(0.138)$ \\
\hline $\mathrm{HDL}$ & $-0.226(0.230)$ & $-0.238(0.205)$ & $-0.109(0.565)$ & $-0.176(0.353)$ & $-0.296(0.112)$ \\
\hline LDL & $0.250(0.182)$ & $0.220(0.244)$ & $0.159(0.402)$ & $0.251(0.180)$ & $0.115(0.545)$ \\
\hline Insülin & $0.042(0.824)$ & $-0.039(0.838)$ & $-0.024(0.901)$ & $0.012(0.948)$ & $-0.044(0.817)$ \\
\hline
\end{tabular}

Abb. ABSl; a body shape index , AVl; abdominal volume index, BAl; Body adiposity index BMI; Body Mass Index, BRl; body roundness index, CIMT; Carotid intima-media thickness, HC; Hip circumference $(\mathrm{cm})$, HDL-C: High density lipoprotein cholesterol, HOMA-IR; homeostasis model assessment -Insulin resistance, LDL-C; Low density lipoprotein cholesterol, TSH; Thyroid stimulant hormone, WC; Waist circumference (cm), WHR; Waist-hip-ratio, WHtR; Waistheight ratio 
Kabat et al. reported that waist/height ratio is an outstanding predictor of glucose, triglyceride and $\mathrm{HDL}$, and waist/height ratio can predict diabetes, dyslipidaemia or hyperuricemia and hypertension better than BMI in postmenopausal women. Besides, Kabat et al. found that when waist/hip ratio was compared to $\mathrm{BMI}$, waist/height ratio or waist circumference, it became the weakest predictor of all cardiometabolic risk factors (15). CIMT is also recently used as a non-invasive indicator in the development of atherosclerosis (16-17). In our study, the mean value of CIMT was found significantly higher in the hypothyroidism groups than the control group. This result shows that cardiovascular disease risk has increased in hypothyroidism. However, there was a positive correlation between CIMT and waist circumference and hip circumference in the subclinical hypothyroidism group in our study, we did not detect a correlation between CIMT and waist/hip ratio.

The adipocytokines originating from visceral adipose tissue is more effective in development of atherosclerosis. The increased visceral adipose tissue, adipocytokines and proinflammatory response have been related with increased insulin sensitivity, dyslipidemia and atherosclerosis (18). However, the enhancement of visceral adipose tissue is generally seen with weight gain, it is reported that the visceral adipose tissue might increase independent of weight gain (19). It is reported that waist circumference measurement was not always sufficient to determine visceral adipose tissue. Especially, it is insufficient in separating subcutaneous adipose tissue and visceral adipose tissue. Therefore, it is important to use new anthropometric measurements to evaluate visceral adipose tissue. The conducted studies have found that BRI has a good distinctive power for diabetes or CVD and risk factors (20-21). BRI is better than waist/height ratio in predicting of body fat and visceral adipose tissue percentages (7). Liet G et al. also reported a significant correlation between $B R I$ and $\mathrm{BMI}$ and waist circumference in over weight and obese patients, and a weak the relationship between BRI and waisthip ratio (22). Similarly, there was a very strong correlation between $\mathrm{BAI}, \mathrm{BRI}$ and $\mathrm{AVI}$ and conventional anthropometric measures including BMI, waist and hip circumferences and waist/height ratio in our study.

While Fujita et al. compared ABSI with BMI or waist circumference, they found that ABSI was not a suitable predictor for hypertension, diabetes and dyslipidaemia in Japanese adults (23). In our study, there was no correlation between $A B S I$ and $B M I$, waist and hip circumferences, waist-height ratio and waist-hip ratio.

The primer limitations of our study are the number of samples in groups and the absence of follow-up period. It might give more information about the relationshıp between CIMT and new anthropometric parameters and the development of cardiovascular events with a wide number of patients.
Cardiovascular disease risk has increased in patients with hypothyroidism and using simple, cheap methods will be beneficial in terms of early detection and treatment. In particular, routine use of new anthropometric measures showing body fat distribution and central obesity will be very useful in terms of cardiovascular risk. We believe that it is possible to use new anthropometric measures in patients with hypothyroidism as an alternative obesity measurement and predictor for cardiovascular diseases. There is a need for extended studies which will be conducted on this topic.

Ethical Approval: This study has been approved by the Ethical Committee for Clinical Researches of KTO Karatay University (Date: 19/06/2020 Number:2020/045).

\section{Author Contributions:}

Concept: G.G.

Literature Review: G.G.

Design : G.G., Y.T.

Data acquisition: G.G.

Analysis and interpretation: G.G., Y.T.

Writing manuscript: G.G., Y.T.

Critical revision of manuscript: G.G., Y.T.

Conflict of Interest: Authors declared no conflict of interest.

Financial Disclosure: Authors declared no financial support.

\section{References}

1. Almandoz JP, Gharib H. Hypothyroidism: Etiology, Diagnosis and Management. Med Clin N Am. 2012; 96(2):20321.

2. Tuğrul A. Hipotiroidi. Özata M, ed. Endokrinoloji Metabolizma ve Diyabet, İstanbul Tıp Kitabevi Yayıncılık, İstanbul, 2011:154-63.

3. Pischon $\mathrm{T}$, Boeing $\mathrm{H}$, Hoffmann K. General and abdominal adiposity and risk of death in Europe. N Engl J Med. 2008;359(20):2105-20.

4. Lee CM, Huxley RR, Wildman RP, Woodward M. Indices of abdominal obesity are better discriminators of cardiovascular risk factors than BMI: a meta-analysis. J Clin Epidemiol. 2008;61(7):646-53.

5. Schneider HJ, Glaesmer H, Klotsche J, Böhler S, Lehnert $\mathrm{H}$, Zeiher AM et al. Accuracy of anthropometric indicators of obesity to predict cardiovascular risk. J Clin Endocrinol Metab. 2007;92(2):589-94.

6. Bergman RN, Stefanovski D, Buchanan TA, Sumner AE, Reynolds JC, Sebring $N$ et al. A better index of body adiposity. Obesity (Silver Spring). 2011;19(5):1083-89.

7. Thomas DM, Bredlau C, Bosy-Westphal A, Mueller M, Shen W, Dympna G et al. Relationships between body roundness with body fat and visceral adipose tissue emerging from a new geometrical model. Obesity (Silver Spring) 2013;21(11):2264-71.

8. Verma A, Jayaraman M, Kumar HK, Modi KD. Hypothyroidism and obesity. Cause or effect? Saudi Med J. 2008; 29(8):1135-38.

9. Hak AE, Pols HA, Visser TJ. Drexhage HA, Hofman A, Witteman JC. Subclinical hypothyroidism is an independent risk factor for atherosclerosis and myocardial infarction in elderly women: the Rotterdam Study. Ann Intern Med. 2000;132(4):270-78. 
10. Valentina VN, Marijan B, Chedo D, Branka K .Subclinical hypothyroidism and risk to carotid atherosclerosis. Arq Bras Endocrinol Metab. 2011;55(7):475-80.

11. Liberopoulos EN, Elisaf MS. Dyslipidemia in patients with thyroid disorders. Hormones (Athens). 2002;1(4):218-23.

12. Eren MA, Torun $A Y$, Ulaş $T$, Aydoğan $T$, Demir $M$, Sabuncu T.Prediyabetik Obezler Kadınlarda Vücut Kompozisyonunu Etkileyen Klinik ve Biyokimyasal Faktörler. Harran Üniversitesi Tıp Fakültesi Dergisi. 2014;11(2): 130-37.

13. Ashwell M, Gunn P, Gibson S. Waist-to-height ratio is a better screening tool than waist circumference and BMI for adult cardiometabolic risk factor: systematic review and meta-analysis. Obes Rev. 2012; 13(3):275-86.

14. Savva SC, Lamnisos D, Kafatos AG. Predicting cardiometabolic risk: waist-to-height ratio or BMI. A meta-analysis. Diabetes Metab Syndr Obes. 2013; 24(6):403-19.

15. Kabat GC, Heo M, Van Horn LV, Kazlauskaite R, Getaneh $\mathrm{A}, \mathrm{Ard} \mathrm{J}$ et al. Longitudinal association of anthropometric measures of adiposity with cardiometabolic risk factors in postmenopausal women. Ann Epidemiol. 2014; 24(12):896-902.

16. Jadhav UM, Kadam NN Carotid intima media thickness as independent predictor of coronary artery disease. Indian Heart J. 2001; 53(4):458-62.

17. Mayet J, Stanton AV, Chapman N, Foale RA, Hughes $A D$, Thom SAMG. Is carotid artery intima media thickening a reliable marker of early atherosclerosis? J Cardiovasc Risk. 2002; 9(2):77-81.

18. Amato MC, Giordano $C$, Galia M, Criscimanna A, Vitabile $S$, Midiri M, et al. Visceral Adiposity Index: a reliable indicator of visceral fat function associated with cardiometabolic risk. Diabetes care. 2010;33(4):920-2.

19. Shimabukuro M, Kozuka C, Taira S, Yabiku K, Dagvasumberel $\mathrm{M}$, Ishida $\mathrm{M}$, et al. Ectopic fat deposition and global cardiometabolic risk: new paradigm in cardiovascular medicine. The journal of medical investigation : JMI. 2013;60(1-2):1-14.

20. Maessen MF, Eijsvogels TM, Verheggen RJ, Hopman $M$, Verbeek A, Vegt F. Entering a new era of body indices: the feasibility of a body shape index and body roundness index to identify cardiovascular health status. PLoS One. 2014;17(9):e107212

21. Chang Y, Guo X, Li T, Li S, Guo J, Sun Y. A body shape index and body roundness index: two new body indices to identify left ventricular hypertrophy among rural populations in northeast China. Heart Lung Circ. 2016; 25(4):358-64.

22. Li G, Wu HK, Wu XW, Cao Z, Tu YC, Ma Y et al. The feasibility of two anthropometric indices to identify metabolic syndrome, insülin resistance and inflammatory factors in obese and overweight adults. Nutrition. 2019; 57:194201.

23. Fujita $M$, Sato $Y$, Nagashima $K$, Takahashi $S$, Hata A Predictive power of a body shape index for development of diabetes, hypertension, and dyslipidemia in Japanese adults: a retrospective cohort study. PLoS One. 2015; 10(6):e0128972. 